\title{
PENGEMBANGAN LKM PENULISAN KARYA ILMIAH BERBASIS LIKIKU PADA MAHASISWA PBSI STKIP NURUL HUDA
}

\author{
Suryani ${ }^{1^{*}}$, Indah Sulmayanti ${ }^{2}$, Diana Melinda ${ }^{3}$ \\ Program Studi Pendidikan Bahasa dan Sastra Indonesia \\ STKIP Nurul Huda OKU Timur \\ suryani@stkipnurulhuda.ac.id \\ Indah81@stkipnurulhuda.ac.id
}

\begin{abstract}
Abstrak
Penelitian ini bertujuan untuk menghasilkan sebuah produk bahan ajar berupa Lembar Kerja Mahasiswa (LKM) pembelajaran Penulisan Karya IImiah untuk mahasiswa Prodi PBSI STKIP Nurul Huda. Metode yang digunakan adalah metode research and development (R\&D) dengan mengadaptasi teori Brog and Gall dari 10 tahapan pengembangan produk menjadi 4 tahap utama pengembangan produk yakni 1) tahap studi pendahuluan, 2) tahap studi pengembangan, 3) tahap validasi dan evaluasi, dan 4) tahap implementasi. Teknik pengumpulan data menggunakan observasi, wawancara, angket, dan tes. Data akan dianalisis berdasarkan jenisnya yakni data kualitatif akan dianalisis dengan membaca, menulis, mengklasifikasi, dan mendeskripsikan, sedangkan data kuantitatif akan dianalisis hasil dari uji kelayakan dan respon mahasiswa. Pada penelitian ini telah berhasil mendesain sebuah produk pembelajaran yang baik untuk MK Penulisan Karya IImiah berupa LKM yang fokus pada materi stuktur penulisan skripsi. LKM ini sudah layak untuk diujikan secara terbatas tetapi untuk uji luas harus mengikuti beberapa saran perbaikan atau catatan revisi dari validator. Hasil angket pengguna memberikan gambaran akan besarnya peluang untuk LKM ini dapat meningkatkan hasil belajar dan keterampilan mahasiswa dalam menulis karya ilmiah.
\end{abstract}

Kata Kunci: LKM, penulisan karya ilmiah, LIKIKU

\section{PENDAHULUAN}

Pemerintah Indonesia senantiasa mendorong laju perkembangan pendidikan melalui berbagai aspek. Salah satunya beasiswa dan berbagai jenis hibah penelitian. Berangkat dari hal ini perguruanperguruan tinggi juga senantiasa mendorong para dosen dan mahasiswanya untuk aktif melakukan kegiatan penelitian dan pengabdian kepada masyarakat sebagai wujud kepatuhan pada Tri Darma Perguruan Tinggi tanpa terkecuali STKIP Nurul Huda. Hal inilah yang mendorong peneliti sebagai salah satu dosen tetap di STKIP Nurul Huda untuk turut serta melakukan penelitian dengan mengikutsertakan mahasiswa Prodi PBSI sebagai salah satu anggotanya.

Objek penelitian kali ini peneliti memilih mahasiswa Program Studi PBSI Semester V untuk kelas Mata Kuliah Penulisan Karya IImiah. Dasar pemilihan ini adalah berangkat dari temuan ketua peneliti yang kebetulan mengampu mata kuliah tersebut terkait kemampuan dan pemahaman mahasiswa yang masih rendah terkait materi menulis karya ilmiah. Hal ini terbukti melalui data nilai mahasiswa yang masih cendrung rendah.

Permasalahan ini tentu saja bukan sepenuhnya merupakan kekurangan dari diri mahasiswa. Sebagai pengajar peneliti menyadari masih belum mengembangankan proses pembelajaran secara lebih optimal. Selama ini peneliti hanya terfokus pada penggunaan buku-buku yang telah ada dan melakukan pembahasan terkait buku yang ada tersebut. Oleh karena itu, peneliti memandang perlunya inovasi yang lebih dalam proses pembelajaran salah satunya adalah mengembangkan sebuah bahan ajar khusus agar lebih fokus dan dapat mencapai hasil yang lebih optimal.

Bahan ajar khusus yang peneliti maksudkan adalah bahan ajar yang terfokus pada materi yang akan diajarkan dengan mengoptimalkan kearifkan lokal agar lebih mengena pada diri mahasiwa yang diajar. Berdasarkan hal ini maka peneliti tertarik menerapkan sebuah hasil penelitian salah satu tim dosen STKIP Nurul Huda yang berhasil meraih hibah PDP 2020 yang mana hasil penelitiannya berupa produk bahan ajar jenis Lembar Kerja Mahasiswa (LKM) berbasis pembelajaran Literasi Kitab Kuning (LIKIKU) yang terbukti dapat membantu mahasiswa dalam memahami materi membaca pemahaman literal. 
PENGEMBANGAN LKM PENULISAN KARYA ILMIAH BERBASIS .... $\mid 13$

Berdasarkan uraian di atas peneliti bermaksud melakukan penelitian serupa dengan objek yang berbeda dan penelitian ini peneliti beri judul Pengembangan Bahan Ajar (LKM) Pembelajaran Penulisan Karya IImiah Berbasis Literasi Kitab Kuning (LIKIKU) pada Mahasiswa Program Studi PBSI STKIP Nurul Huda Sukaraja 2021. Berdasarkan latar belakang masalah di atas rumusan masalah dalam penelitian ini adalah bagaimanakan pengembangan bahan ajar yang sesuai untuk Mata Kuliah Penulisan Karya IImiah? Sejalan dengan latar belakang masalah dan rumusan masalah yang telah diuraikan maka tujuan penelitian ini adalah untuk menghasilkan sebuah produk bahan ajar berupa Lembar Kerja Mahasiswa (LKM) pembelajaran Penulisan Karya IImiah yang berbasis pembelajaran Literasi Kitab Kuning (LIKIKU).

Sebuah proses pembelajaran terikat dengan aturan yang telah tercantum dalam sebuah kurikulum pendidikan. Kurikulum sendiri memiliki banyak komponen yang diuraikan secara terperinci. Salah satu komponen dalam kurikulum yang harus disampaikan kepada peserta didik dan memiliki peran sebagai materi pembelajaran di dalam proses pembelajaran adalah bahan ajar (Nisa, 2019).

Bahan ajar adalah semua bentuk bahan yang disusun secara sistematis dan dirancang sesuai kurikulum yang berlaku sehingga memungkinkan peserta didik dapat belajar dengan baik serta memungkinkan seorang tenaga pengajar lebih runtut dalam menyampaikan materi pembelajarannya dan kopetensi yang telah ditentukan sebelumnya dapat tercapai (Lestari, dikutip oleh Simaremare, 2018).

Pendapat tersebut dirperkuat oleh salah satu pendapat yang menyatakan bahwa bahan ajar adalah segala bentuk bahan yang digunakan untuk membantu tenaga pendidik dalam melaksanakan proses pembelajaran di kelas dan memungkinkan peserta didik untuk memahami suatu kopetensi secara lebih mudah dan terartur (Majid, 2013).

Berdasarkan pendapat-pendapat di atas maka, menurut hemat peneliti sebuah bahan ajar dapat diartikan sebagai segala bentuk bahan yang disusun secara sistematis berdasarkan kurikulum yang berlaku dan memiliki peran sebagai materi pembelajaran yang digunakan oleh tenaga pendidikan untuk mempermudah proses pembelajaran yang dilakukannya sehingga memungkinkan siswa dapat belajar dan memahami suatu kompetensi yang ingin dicapai secara lebih mudah dan praktis.

Bahan ajar sendiri memiliki berbagai jenis baik yang cetak seperti handout, buku, brosur, lembar kerja siswa/mahasiswa, dll maupun noncetak yakni dapat berupa bahan ajar dengar seperti kaset ataupun bahan ajar audio-visual seperti video atau film (Lestari dikutip oleh Simaremare, 2018). Bentuk bahan ajar yang akan diupayakan dalam penelitian ini berupa bahan ajar bentuk cetak yakni Lembar Kerja Mahasiswa (LKM). Sebagaimana dengan yang tertuang dalam judul penelitian dan termuat dalam uraian latar belakang masalah maka, LKM yang akan disusun oleh peneliti ini telah disesuaikan dengan pembelajaran Literasi Kitab Kuning (LIKIKU).

Pembelajaran adalah kegiatan yang direncankan dengan mengkondisikan atau menstimulus seseorang agar dapat belajar dengan baik sehingga kegiatannya berfokus pada dua kegiatan utama yaitu bagaina merubah tingkah laku sesorang dan bagaimana menyampaikan sebuah ilmu pengetahuan melalui kegiatan belajar-mengajar (Pane dan Muhammad, 2017).

Literasi identik dengan kemampuan berbahasa pada diri seseorang karena literasi sendiri mengacu pada keteranmpilan membaca dan menulis yang tentunya tidak terlepas dari dua ketampilan berbahasa lainnya yakni ketampilan menyimak dan ketarampilan berbicara (Sumadiyo, 2011). Lebih lanjut dikatakan pula bahwa sesorang yang memiliki kemampuan berbahasa yang baik disebut sebagai orang yang yang literate atau orang yang terdidik.

Kitab kuning sendiri mengacu pada kitab-kitab yang tradisonal yang berisi pembahasan mengenai ilmu-ilmu keagamaan (Agama Islam) dimana pada masa dulu kitab ini kebanyakan ditulis pada lembaran kertas berwarna kuning (Brunaissen, 2012). Kitab kuning ditulis dengan menggunakan huruf Arab tanpa harakat sehingga selain disebut kitab kuning dikenal juga dengan istilah kitab gundul (Azra, 2001).

Pembelajaran literasi kitab kuning merujuk pada metode pembalajaran khas pesantren yang meliputi lima metode pembelajaran yakni; maknani, sorogan, bandongan, musyawarah, dan muhafadoh (Fitriyah, 2019: 23-25). Lebih lanjut dikatakan pula bahwa literasi kitab kuning ini memiliki kelengkapan unsur literasi dengan kelualitas yang tinggi serta dimungkinkan untuk dapat diterapkan pada pembelajaran dengan materi yang lebih umum (Fitriyah dkk, 2019).

Pada artikel selanjutnya yang merupakan hasil penelitian lanjutan dari pernyataan pendapat di atas mengemukakan bahwa pembelajaran Literasi Kitab Kuning (LIKIKU) yang diterapkan pada pembelajaran dengan materi yang umum memerlukan modifikasi berupa susunan dan cara penerapan

Suryani, Indah Sulmayanti, Diana Melinda 
langkah pembelajaran serta alih istilah (Suryani dkk, 2020).

Lebih lanjut terlihat dari hasil penelitian sebelumnya berupa produk LKM yang dihasilkan dalam penelitian tersebut langkah-langkah pembelajaran Likiku dibuat urutan dan perubahan penggunaan istilah dari bahasa Arab ke bahasa Indonesia sebagai berikut; hafalan (Muhafadoh) menghafalkan ringkasan materi praktis, kodefikasi, dan penanda letak, kodefikasi (Maknani) memberikan kode dan penanda letak pada teks yang dibahas, latihan terpimpin (Bandongan) mengamati langkah pengerjaan yang dicontohkan langsung oleh dosen, latihan mandiri 1 (Sorogan) latihan mandiri dan dipersentasikan di depan dosen secara individual, dan latihan mandiri 2 (Musyawarah) latihan berkelompok yang hasilnya dipersentasikan dan didiskusikan di depan kelas dimana satu kelompok persentasi dan kelompok yang lain menanggapi (Suryani dkk, 2020).

\section{METODE PENELITIAN}

Metode penelitian yang digunakan dalam penelitian ini adalah metode pengembangan model (reseacrh and development) dengan mengadaptasi teori dari Borg dan Gall (Gall, 2003). Sebagaimana diungkapkan dalam teori Borg dan Gall yang terdiri dari 10 tahap penelitian, maka dalam penelitian ini tahapan tersebut diadaptasi dan dikristalkan menjadi 4 tahapan utama yakni; 1) tahap studi pendahuluan, 2) tahap studi pengembangan, 3) tahap setudi validasi dan evaluasi, dan 4) tahap implementasi. Pendekatannya adalah pendekatan campuran (mix method) yaitu menggabungkan pendekatan kualitatif dan pendekatan kuantitatif di dalam satu penelitian.

Penelitian dilakukan dengan 3 tahapan utama yakni;

1. Tahap Persiapan

1) Mengobservasi lapangan untuk menemukan berbagai permasalahan (prapenelitian)

2) Menentukan permasalahan yang akan diangkat

3) Menyusun proposal

4) Melakukan tahap studi pendahuluan (kajian literatur, analisis kebutuhan, analisis dokumen/silabus, dan analisis materi ajar).

5) Menyebarkan angket kepada mahasiswa, melakukan wawancara dengan beberapa mahasiswa, dan melaksanakan pretest kepada mahasiswa.

2. Tahap Pelaksanaan

Pada tahap ini dilaksanakan tahap pengembangan bahan ajar ke-2, ke-3, dan ke-4.

1) Melakukan tahap pengembangan (menyusun teks dan format/desain bahan ajar dalam hal ini LKM).

2) Melakukan tahap validasi dan evaluasi (tahap uji ahli, tahap revisi awal, tahap uji lapangan, dan tahap revisi akhir).

3. Tahap Akhir

1) Mengolah data kualitatif dan data kuantitatif

2) Menarik kesimpulan hasil penelitian

3) Menyusun laporan akhir penelitian

Intrumen dalam penelitian ini adalah lembar observasi, teks wawancara/daftar pertanyaan, dan lembar angket. Ketiganya menggunakan intrumen yang telah dilakukan pada penelitian terdahulu sihingga telah diuji validasi dan reliabelitasnya sebgai alat ukur. Data dalam penelitian ini dikumpulkan dengan beberapa teknik yakni; teknik observasi, teknik wawancara, dan teknik penyebaran angket. Teknik observasi dan wawancara digunakan untuk mengamati kondisi awal sebelum dilaksanakan kegiatan inti penelitian. Teknik angket dilakukan dua kali yakni sebelum penelitian dan setelah penelitian untuk kemudian datanya diolah untuk menentukan hasil penelitian.

Penelitian ini memiliki dua jenis data yakni data kualitatif (dihasilkan dari proses observasi, wawancara, dan angket) dan data kuantitatif (diperoleh melalui teknik tes berupa nilai mahasiswa terkai Mata Kuliah Penulisan Karya IImiah). Data kualitatif dianalisis dengan cara membaca, menulis, mengklasifikasikan, dan mendeskripsikan. Data kuantitatif yang diperoleh dari skor nilai tes (pre-test dan post-test) akan diolah dengan uji-t. Sedangan pengembang produk LKM akan dilakukan berdasarkan desain penelitian berikut (sedain dihasilkan dari mengadaptasi 10 langkah pengembangan bahan ajar oleh Borg dan Gall menjadi empat tahap utama). 


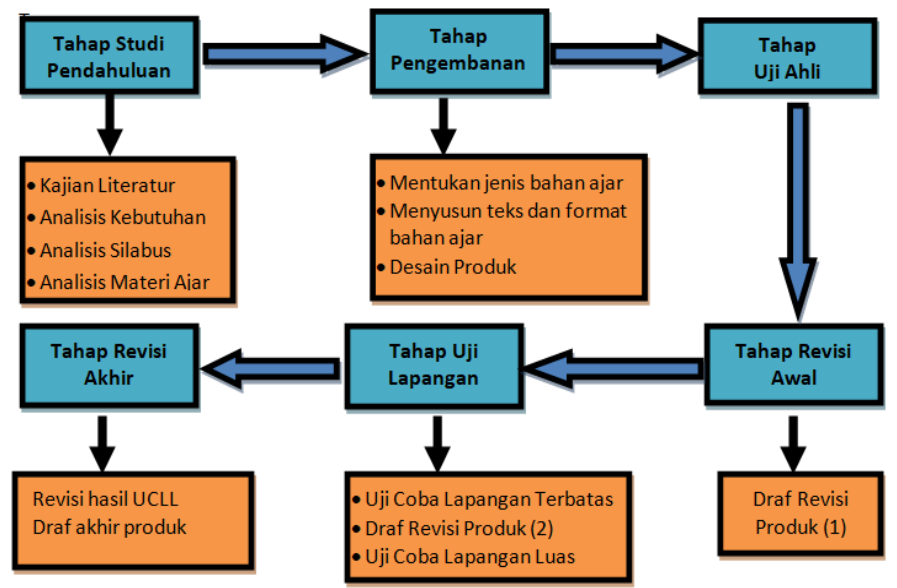

Gambar 1. Desain Penelitian Pengembangan Bahan Ajar

\section{HASIL DAN PEMBAHASAN}

\section{HASIL}

\section{a. Hasil Observasi dan Wawancara}

Tabel 4.1

Hasil Analisis Observasi dan Wawancara

\begin{tabular}{|c|c|c|}
\hline No & Komponen Observasi & Hasil yang Diperoleh \\
\hline 1 & Metode pembelajaran & $\begin{array}{l}\text { 1. Metode yang digunakan dosen cukup variatif dan bersifat } \\
\text { kolaboratif. } \\
\text { 2. Pembelajaran bentuk kolaboratif yang terlalu dominan } \\
\text { menjadikan kemampuan per individu mahasiswa kurang } \\
\text { terlihat jelas. } \\
\text { 3. Dibutuhkan metode/model pembelajaran yang mampu } \\
\text { mengidentifikasi kemampuan individual dengan tetap } \\
\text { mengutamakan efisiensi waktu pembelajaran yang } \\
\text { terbatas. }\end{array}$ \\
\hline 2 & Sarana dan Prasarana & $\begin{array}{l}\text { Sarana dan prasarana sudah cukup memadai dengan } \\
\text { tersedianya sinyal jaringan Wifi, alat-alat pendukung proses } \\
\text { pembelajaran. }\end{array}$ \\
\hline 3 & Media Pembelajaran & $\begin{array}{l}\text { Media pembelajaran menjadi catatan khusus. Selama ini } \\
\text { media yang digunakan hanya bersifat teori dan tidak cukup } \\
\text { untuk menunjang penguatan keterampilan menulis karya } \\
\text { ilmiah yang bersifat individual. }\end{array}$ \\
\hline 4 & Minat Belajar & $\begin{array}{l}\text { Sebagaian besar mahasiswa memiliki minat yang rendah } \\
\text { karena cendrung menganggap mata kuliah penulisan karya } \\
\text { ilmiah sebagai mata pelajaran dengan tingkat kesulitan tinggi, } \\
\text { menyita waktu, dan sangat kompleks sehingga sulit untuk } \\
\text { dipahami. Hal ini menyebabkan sebagian besar justru "kalah" } \\
\text { sebelum memulai. Hal ini diperparah oleh metode kolaborasi } \\
\text { karena sulit untuk mengotrol kemampuan secara individual. }\end{array}$ \\
\hline 5 & Harapan & $\begin{array}{l}\text { Adanya metode dan media (bahan ajar) yang dapat } \\
\text { mendukung proses pembelajaran, khususnya dapat } \\
\text { meningkatkan keterampilan mahasiswa secara individual } \\
\text { terlebih mengingat mata kuliah ini akan sangat dibutuhkan } \\
\text { guna menyelesaikan tugas akhir perkuliahan (skripsi). }\end{array}$ \\
\hline
\end{tabular}


Tabel 4.2

Hasil Validasi Ahli

\begin{tabular}{|c|c|c|c|c|}
\hline No & $\begin{array}{c}\text { Aspek } \\
\text { yang } \\
\text { Dinilai }\end{array}$ & Validator 1 & Validator 2 & Validator 3 \\
\hline 1 & $\begin{array}{l}\text { Kelayakan } \\
\text { Materi }\end{array}$ & $\begin{array}{l}\text { Materi sudah memadai } \\
\text { namun kurang } \\
\text { sistematis. Perlu } \\
\text { penyusunan ulang } \\
\text { agar mempermudah } \\
\text { proses pembelajaran. }\end{array}$ & $\begin{array}{l}\text { Beberapa langkah dalam } \\
\text { penerapan materi yang } \\
\text { bersifat praktik masih } \\
\text { terlalu memaksakan } \\
\text { sehingga justru } \\
\text { berpeluang menyulitkan } \\
\text { mahsiswa dalam praktik } \\
\text { penulisan. Perlu dilakukan } \\
\text { penyesuaian ulang } \\
\text { sehingga dapat lebih } \\
\text { sistematis. }\end{array}$ & $\begin{array}{l}\text { Materi sudah } \\
\text { memadai namun } \\
\text { mengingat materi } \\
\text { yang sangat luas } \\
\text { maka LKM harus } \\
\text { hanya terfokus pada } \\
\text { yang sifatnya praktik } \\
\text { langsung saja. }\end{array}$ \\
\hline 2 & $\begin{array}{l}\text { Kelayakan } \\
\text { Bahasa }\end{array}$ & $\begin{array}{l}\text { Bahasa yang } \\
\text { digunakan sudah } \\
\text { memiliki tingkat } \\
\text { keterbacaan yang } \\
\text { baik. }\end{array}$ & $\begin{array}{l}\text { Bahasa yang digunakan } \\
\text { sudah baik dan sesuai } \\
\text { dengan kaidah berbahasa } \\
\text { yang baik dan benar. }\end{array}$ & $\begin{array}{l}\text { Bahasa dapat } \\
\text { dipahami dengan baik } \\
\text { namun perlu } \\
\text { perbaikan pada } \\
\text { redaksi pada kalimat } \\
\text { perinta/petunjuk } \\
\text { pelaksanaan. }\end{array}$ \\
\hline 3 & $\begin{array}{l}\text { Kelayakan } \\
\text { Desain }\end{array}$ & $\begin{array}{l}\text { Terlalu banyak warna } \\
\text { justru kurang cocok } \\
\text { untuk metal belajar } \\
\text { mahasiswa yang } \\
\text { cendrung serius. } \\
\text { Bagian latihan individu } \\
\text { penatatan letaknya } \\
\text { perlu diperhatikan } \\
\text { ulang. }\end{array}$ & $\begin{array}{l}\text { Pada latihan penulisan } \\
\text { terbatas dan sangat } \\
\text { memungkinkan banyak } \\
\text { ruang kosong tidak } \\
\text { terpakai. Perlu menyiasati } \\
\text { desain LKM agar lembar } \\
\text { kosong minim namun } \\
\text { reasi mahasiswa tidak } \\
\text { terlalu dibatasi. }\end{array}$ & $\begin{array}{l}\text { Bebera langkah harus } \\
\text { disesuaikan dengan } \\
\text { materi perlu } \\
\text { pengkajian ulang akar } \\
\text { lebih sitematis dan } \\
\text { optimal. Permainan } \\
\text { huruf kodefikasi harus } \\
\text { lebih variatif sehingga } \\
\text { mudah dibedakan. }\end{array}$ \\
\hline
\end{tabular}

c. Hasil Analisis Angket

Tabel 4.3

Kisi-Kisi Angket Kelayakan LKM

\begin{tabular}{|c|l|c|c|c|c|c|}
\hline \multirow{2}{*}{ No } & \multirow{2}{*}{ Aspek yang dinilai } & \multicolumn{3}{c|}{ Skor Penilaian } & \multirow{2}{*}{ Ket } \\
\cline { 3 - 6 } & & $\mathbf{1}$ & $\mathbf{2}$ & $\mathbf{3}$ & $\mathbf{4}$ & \\
\hline 1 & Kelayakan Materi & & & & & \\
\hline 2 & Kelayakan Bahasa & & & & & \\
\hline 3 & Kelayakan Desain & & & & & \\
\hline
\end{tabular}

Tabel 4.4

Hasil Analisis Kelayakan LKM

\begin{tabular}{|c|c|c|c|c|c|c|c|c|c|c|c|c|c|c|c|}
\hline \multirow{2}{*}{ No $R$} & \multicolumn{14}{|c|}{ Nomor Butir Angket } & \multirow{2}{*}{$\mathbf{T}$} \\
\hline & 1 & 2 & 3 & 4 & 5 & 6 & 7 & 8 & 9 & 10 & 11 & 12 & 13 & 14 & \\
\hline $\mathrm{R} 1$ & 3 & 5 & 3 & 5 & 2 & 3 & 5 & 3 & 4 & 5 & 2 & 5 & 4 & 3 & 52 \\
\hline $\mathrm{R} 2$ & 5 & 5 & 5 & 5 & 5 & 5 & 5 & 5 & 5 & 5 & 5 & 5 & 5 & 5 & 70 \\
\hline R3 & 4 & 5 & 3 & 5 & 2 & 4 & 5 & 4 & 4 & 5 & 2 & 5 & 4 & 3 & 55 \\
\hline $\mathrm{R} 4$ & 4 & 4 & 5 & 5 & 2 & 4 & 4 & 4 & 3 & 5 & 2 & 4 & 5 & 4 & 55 \\
\hline R5 & 3 & 5 & 3 & 5 & 2 & 3 & 5 & 3 & 4 & 5 & 2 & 5 & 4 & 3 & 52 \\
\hline R6 & 5 & 5 & 5 & 5 & 5 & 5 & 5 & 5 & 5 & 5 & 5 & 5 & 5 & 5 & 70 \\
\hline
\end{tabular}

Suryani, Indah Sulmayanti, Diana Melinda 


\begin{tabular}{|c|c|c|c|c|c|c|c|c|c|c|c|c|c|c|c|}
\hline $\mathrm{R} 7$ & 3 & 5 & 5 & 5 & 5 & 3 & 5 & 3 & 5 & 5 & 5 & 5 & 5 & 5 & 64 \\
\hline $\mathrm{R} 8$ & 5 & 5 & 5 & 5 & 5 & 5 & 5 & 5 & 5 & 5 & 5 & 5 & 5 & 5 & 70 \\
\hline $\mathrm{R} 9$ & 4 & 4 & 5 & 5 & 2 & 4 & 4 & 4 & 3 & 5 & 2 & 4 & 5 & 4 & 55 \\
\hline $\mathrm{R} 10$ & 4 & 5 & 5 & 5 & 5 & 4 & 5 & 4 & 5 & 5 & 5 & 5 & 5 & 5 & 67 \\
\hline $\mathrm{R} 11$ & 5 & 4 & 3 & 5 & 2 & 5 & 5 & 5 & 4 & 5 & 2 & 5 & 5 & 3 & 58 \\
\hline $\mathrm{R} 12$ & 5 & 5 & 5 & 5 & 5 & 5 & 5 & 5 & 5 & 5 & 5 & 5 & 5 & 5 & 70 \\
\hline $\mathrm{R} 13$ & 3 & 4 & 5 & 5 & 2 & 3 & 4 & 3 & 3 & 5 & 2 & 4 & 5 & 4 & 52 \\
\hline $\mathrm{R} 14$ & 5 & 5 & 3 & 5 & 2 & 5 & 5 & 5 & 4 & 5 & 2 & 5 & 4 & 3 & 58 \\
\hline $\mathrm{R} 15$ & 2 & 4 & 5 & 5 & 2 & 2 & 4 & 2 & 3 & 5 & 2 & 4 & 5 & 3 & 48 \\
\hline $\mathrm{T}$ & 60 & 70 & 65 & 75 & 48 & 60 & 71 & 60 & 62 & 75 & 48 & 71 & 71 & 60 & 896 \\
\hline
\end{tabular}

Tabel 4.5

Rekapitulasi Hasil Perhitungan Angket Kelayakan LKM

\begin{tabular}{|c|c|c|c|}
\hline No.I P & Skor & Persentase (\%) & Kategori \\
\hline 1 & 60 & 80 & Layak \\
\hline 2 & 70 & 93,3 & Layak \\
\hline 3 & 65 & 86,6 & Layak \\
\hline 4 & 75 & 100 & Layak \\
\hline 5 & 48 & 64 & Cukup Layak \\
\hline 6 & 60 & 80 & Layak \\
\hline 7 & 71 & 94,6 & Layak \\
\hline 8 & 60 & 80 & Layak \\
\hline 9 & 62 & 82,6 & Layak \\
\hline 10 & 75 & 100 & Layak \\
\hline 11 & 48 & 64 & Cukup Layak \\
\hline 12 & 71 & 94,6 & Layak \\
\hline 13 & 71 & 94,6 & Layak \\
\hline 14 & 60 & 80 & Layak \\
\hline Jumlah & 942 & 1194,3 & Layak \\
\hline Rata-rata & 67,2 & 85,31 & \\
\hline
\end{tabular}

\section{Pembahasan}

\section{a. Studi Pendahuluan}

Analisis kebutuhan dengan menganalisis dokumen pembelajaran, observasi, dan wawancara dengan panduan yang telah ada. Berdasarkan hasil observasi dan wawancara diketahui bahwa selama ini belum ada bahan ajar yang memadai untuk MK Penulisan Karya IImiah sehingga perlu dibuat satu produk bahan ajar khusus. Validitas angket menggunakan content validity yakni dengan adanya kisi-kisi angket dan reliabelitasnya dapat dinyatakan redymet karena telah digunakan pada penelitian sebelumnya sehingga dianggap telah reliabel. Hasil analisis angket menunjukan minat belajar mahasiswa yang masih rendah dengan alasan utamanya mereka beranggapan bahwa MK Penulisan Karya IImiah adalah matakuliah dengan beban yang berat, sulit dipahami, dan tidak adanya media penunjang yang menarik.

Sebagaimana hasil observasi, wawancara, dan angket hasil analisis silabus/RPS Pembelajaran MK Penulisan Karya IImiah juga menunjukan perlunya bahan ajar yang mendukung untuk meningkatkan keterampilan penulisan karya ilmiah yang bersifat praktik langsung. Berdsarkan analissis materi ditarik simpulan berupa pembatasan ruang kerja LKM pada satu sub materi mengingat luasnya materi Pembelajaran Menulis Karya IImiah. Secara kesulurahan dari hasil studi pendahuluan adalah perlu adanya bahan ajar pendukung. 


\section{b. Pengembangan Produk}

Produk yang dikembangkan dalam penelitian ini adalah sebuah produk bahan ajar berupa Lembar Kerja Mahasiswa (LKM) Mata Kuliah Penulisan Karya IImiah. Desain awal produk mengikuti hasil desain akhir dari penelitian sebelumnya sebagai berikut. Desain tersebut lantas dimodifikasi sesuai dengan hasil validasi ahli untuk disesuaikan dengan materi MK Penulisan Karya IImiah dan dihasilkanlah desain berikut.

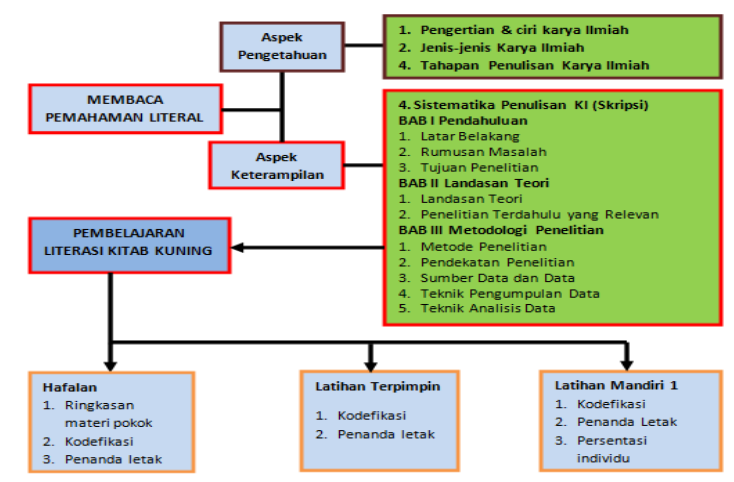

Gambar 2. Desain LKM Penulisan Karya IImiah

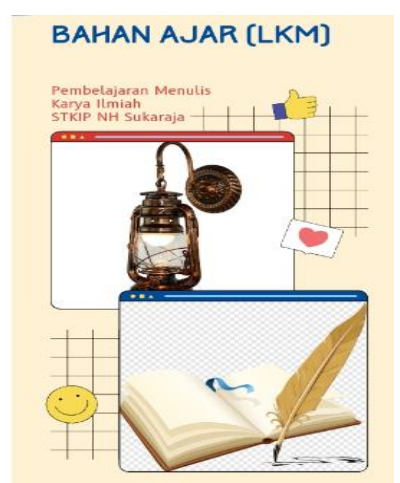

Gambar 3. Sampul LKM Penulisan Karya IImiah

\section{c. Validasi dan Evaluasi}

Bahan ajar Penulisan Karya IImiah yang telah dicetak selanjutnya divalidasi oleh 3 validator. Bahan ajar LKM dinilai berdasarkan 3 aspek, yaitu aspek kelayakan materi, aspek kelayakan bahasa, dan aspek kelayakan desain/media. Setiap aspek divalidasi oleh 3 orang validator yang terdiri dari dosen dan teman sejawat. Hasil validasi oleh Dr. Desi Wardiyah, M.Pd., Liza Murniviyanti, M.Pd., dan Lailatul Fitriyah, M.Pd. Hasil analisisnya adalah Bahan Ajar Pembelajaran Penulisan Karya Ilmiah berupa LKM berbasis LIKIKU layak diujicobakan dalam skala terbatas, tetapi tetap harus ada revisi.

\section{d. Implementasi}

Berdasarkahn hasil validasi pakar dan teman sejawat maka LKM ini hanya akan diujikan secara terbatas dengan berpedoman pada angket penelitian sebagaimana yang telah disepakati kepada beberapa responden (mahasiswa) yang dipilih secara acak sebanyak 15 mahasiswa baik dari kampus $B$ maupun kampus $C$ dengan 14 butir pertanyaan dari 3 aspek pertanyaan. Hasil angket tersebut dapat dilihat pada Tabel 4.4. dan Tabel 4.5 berdasarkan kedua tabel tersebut dapat diperoleh persentasi skor nilai $85,31 \%$ menunjukan bahwa LKM Penulisan Karya IImiah layak untuk digunakan sebagai pendukung proses pembelajaran sehingga berpeluang besar untuk dapat meningkatkan hasil pembelajaran. 
Bahan ajar sangat dibutuhkan dalam proses pembelajaran sehingga tidak dapat diabaikan terutama untuk materi-materi yang bersifat praktis. Pemilihan bentuk bahan ajar seperti LKM ini sangat cocok untu mendeteksi kemampuan individu mahasiswa dengan tetap memperhatikan efisiensi waktu pembelajaran yang singkat. Pada penelitian ini telah berhasil mendesain sebuah produk pembelajaran yang baik untuk MK Penulisan Karya IImiah berupa LKM yang fokus pada materi stuktur penulisan skripsi. LKM ini sudah layak untuk diujikan secara terbatas namun untuk uji luas harus mengikuti beberapa saran perbaikan atau catatan revisi dari validator. Hasil angket pengguna memberikan gambaran akan besarnya peluang untuk LKM ini dapat meningkatkan hasil belajar dan keterampilan mahasiswa dalam menulis karya ilmiah.

Perlu dilakukan penelitian serupa pada mata kuliah yang sama tetapi dengan materi yang berbeda sehingga dapat terwujud LKM yang lengkap untuk seluruh materi Penulisan Karya IImiah. Peneliti lanjutan juga disarankan untuk memodifikasi LKM menjadi e-LKM sehingga lebih praktis untuk digunakan kapanpun dan dimanapun.

\section{UCAPAN TERIMAKASIH}

Ucapan terima kasih peneliti sampaikan kepada STKIP Nurul Huda yang melalui LPPMnya telah membiayai dan memfasilitasi penelitian ini. Tidak lupa pula peneliti ucapkan terima kasih kepada para senior, rekan, dan mahasiswa yang telah memberi masukan dan dukungan kepada peneliti.

\section{DAFTAR PUSTAKA}

Azra, A. 2001. Pendidikan Islam Tradisional dan Modern Menuju Melenium Baru. Bandung: Mizan.

Burnaissen, M. 2012. Kitab Kuning, Pesantren, dan Tarekat. Yogyakarta: Gading Publishing.

Fitriyah, Lailatul. Dkk. 2019. Pendidikan Literasi pada Pembelajaran Kitab Kuning di Pondok Pesantren Nurul Huda Sukaraja OKU Timur. Titian Ilmu.Vol.11 (1). https://journal.stkipnurulhuda.ac.id/index.php/JTI/article/view/351/206. Diakses pada tanggal 12 Agustus2019

Gal, Meredith D., Gall, Joyce P\& Borg, Walter R. 2003. Educational Research: An Introduction. 7th edition. Boston: Pearson Education. Inc.

Majid, Abdul. 2013. Perencanaan Pembelajaran: Mengembangkan Standar Kompetensi Guru. Bandung: PT Remaja Rosdakarya.

Nisa, Hany Uswatun. 2019. Pengembangan Bahan Ajar Bahasa Indonesia Berbasis Kontekstual untuk Siswa Kelas V SD. Jurnal Cakrawala Pendas, Vol 5, No. 2. Diakses 19 Desember 2020.

Pane, Aprida \& Muhammad Darwis Dasopang. 2017. Belajar dan Pembelajaran. Padangsidempuan: Jurnal Fitrah Vol.03 No.2. Diakses 22 Desember 2020

Simaremare. 2018. Pengembangan Bahan Ajar Bahasa Indonesia Bergambar pada Materi "Teks Percakapan" pada Siswa Kelas V SD ST. Yosept Medan. Jurnal Edukasi Kultura, Vol.5, No.2. Diakses 19 Desember 2020.

Sumadiyo, Samsu. 2011. Strategi dan Teknik Pembelajaran Membaca. Yogyakarta: Graha Ilmu.

Supriyadi. 2013. Penulisan Karya Ilmiah dengan Pendekatan Konstruktivisme: Pembelajaran Menulis Karya IImiah yang Inovatif dan Konstruktif. Gorontalo: UNG Press Gorontalo.

Suryani, Hastuti Retno Kuspiyah, dan Lailatul Fitriyah. 2020. Pengembangan Bahan Ajar Pembelajaran Membaca Pemahaman Literal Berbasis Literasi Kitab Kuning pada Mahasiswa Program Sudi PBSI STKIP Nurul Huda Sukaraja. Jurnal Geram. Vol.8, No.2. Diakses 22 desember 2020. 